\title{
What makes authoritarian capitalism Authoritarian? The double erosion of the private- public divide in illiberal Hungary
}

Dorottya Sallai, University of Greenwich, D.Sallai@greenwich.ac.uk Gerhard Schnyder, Loughborough University London, G.Schnyder@1boro.ac.uk

\begin{abstract}
For several decades, the Business and Society literature has mainly focused on the retreat of the state from the economy in Western countries since the 1980s. As a result, the "return of the state" as an economic actor, especially in emerging markets, has left scholars without the necessary tools to capture this trend of the "politicization of the economic." Thus, we argue that current conceptualizations of state-dominated systems as "authoritarian capitalism" too easily lump together countries as diverse as China, Singapore, and Norway under this heading. Rather than considering any type of state intervention in the economy as authoritarian, we propose a more sophisticated conceptualization of the extension of the political into the economic, which allows us to clearly distinguish cases of "state capitalism" from "authoritarian capitalism." We apply our framework to the case of Hungary to illustrate that a more precise definition of "authoritarian capitalism" makes it a useful tool to understand contexts beyond the Chinese case in which it first emerged. Based on interviews with business leaders in Hungary under Viktor Orbán's government, we identify the mechanisms by which an authoritarian government expands the political into the economic realm, eroding the publicprivate divide; moving thus from "democratic backsliding" into "economic backsliding." [205 words]
\end{abstract}

JEL Codes: P16, P26, H13

Key words: Authoritarian capitalism, State capitalism, Political CSR, state-business relationships, post-socialism 
In recent decades, debates about the role of the state and government in the economy have been marked by its retreat from the economic domain and the shift from an interventionist- to a socalled regulatory state (Majone, 1994). Thus, the Business and Society literature has been dominated by a focus on "the economization of the political," i.e. the trend towards a retreat of the state from traditionally state-dominated areas and private companies taking over state functions (Gond et al., 2011: 662). The "political CSR" (Garriga \& Melé, 2004; Scherer \& Palazzo, 2007) and "Corporate Citizenship” (Aßländer \& Curbach, 2017; Davis, 1973; Matten \& Crane, 2005; Moon, Crane, \& Matten, 2005) literatures that focus on the increasingly political role of private companies reflect this trend. While the "economization of the political" has hence seen considerable academic attention, the opposite direction of this process of "socio-economic hybridization" (Gond et al 2011: 664) between state and business, namely the process of "politicization of the economic" (Gond et al 2011: 662) has received much less attention. This implied that a recent trend labelled the "return of the state" (Bremmer, 2008; Kurlanzik, 2016) as an active player in the economy in many countries, has caught Business and Society scholars off guard. Indeed, our theoretical and conceptual tools to study the "politicization of the economic" are much less developed than those to understand the "economization of the political" (see Gond et al., 2011).

Management scholars often attempt to account for the return of the state by simply focusing on the ownership function of the state (Cazurra, Inkpen, Musacchio, \& Ramaswamy, 2014; Inoue, Lazzarini, \& Musacchio, 2013; Musacchio, Lazzarini, \& Aguilera, 2015), and label state capitalism an economic system where the state holds significant ownership stakes in commercial business enterprises (Kurlantzick, 2016). Conversely, attempts to apply the Varieties of Capitalism (VoC) (Hall \& Soskice, 2001) approach to understand the "return of the state" as an economic actor in developing countries, have remained somewhat unconvincing (e.g. Hofman, Moon, \& Wu, 2017; Situ, Tilt, \& Seet, 2018), because this 
perspective exclusively focusses on the role of the state as a regulator, not an active player, which corresponds with the neoliberal regulatory state model that has emerged since the 1980s (Majone, 1994). Yet, even attempts to remedy this shortcoming by applying typologies of states drawn from the national governance and business systems literatures (Evans, 1995; Hollingsworth \& Boyer, 1997; Whitley, 2007) have focused on broad-brush typologies usually distinguishing regulatory-, welfare-, developmental-, and predatory states (Fainshmidt, Judge, Aguilera, \& Smith, 2018; Witt et al., 2017) - that do not do justice to the complexities of modern forms of state-dominated economies. Indeed, these approaches have led scholars to too easily characterize as authoritarian capitalism any economy with a more interventionist state than the Western ideal of the "regulatory state;" including countries like Norway (Situ et al., 2018: 9).

In this paper, we argue that the "return of the state" makes it even more important to take seriously the "politicization of the economic" and further develop our understanding of the role of government in the economy that authors in the area of CSR have noted (Gond et al., 2011; Moon, Kang, \& Gond, 2010). We develop a more sophisticated conceptualization of what makes state intervention in the economy "authoritarian" in order to turn the concept "authoritarian capitalism" into a useful analytical tool beyond the Chinese case in which it was first developed (Witt \& Redding, 2014; Hofman et al., 2017) and to clearly distinguish it from "state capitalism." Indeed, China is not the only country where a trend towards a more authoritarian form of capitalism can be observed. Different post-socialist countries in Central and Eastern Europe - including Russia, Hungary, and Poland - are currently experiencing a shift from the initial post-socialist trajectory towards Western-style liberal-democratic capitalism to a more authoritarian, state-dominated one, which has led political scientists to talk about "democratic backsliding” (Greskovits, 2015; Sedelmeier, 2014; Orenstein, 2013). The concept of authoritarian capitalism - enhanced with a more nuanced definition of what is 
authoritarian about this type of capitalism - can be a useful concept to capture the economic role of a certain type of state in non-Western economies beyond the case of China.

To achieve this, we develop a conceptualization of state- and authoritarian capitalism, that refers to their emergence as a shift of the boundary between the public and the private domains. In both cases, the public domain is further expanded in to the economic domain in a process of "politicization of the economic." Yet, while in the former case this expansion happens through means that respect the principle of the Rule of Law (RoL) including the principle of self-limitation of state power (Chen \& Deakin, 2015), authoritarian capitalism is distinct in that the government violates these principles. Furthermore, while the expansion of the political into the economic in the state capitalist case happens for reasons related to some notion of the "public interest," in the latter case a second erosion of the boundary between the public and the private takes place in that the state interest is increasingly identified with the private interests of the governing elite group. This conceptualization of state- and authoritarian capitalism suggests that it is key to go beyond classifying systems as "authoritarian" simply based on the "tools" of state intervention - such as regulation, incentives, and ownership (Situ et al., 2018). Rather, we propose to investigate these "tools" as mechanisms in Bunge's (2004) sense, whose nature allows us to distinguish between authoritarian and non-authoritarian statedominated systems. As such these mechanisms play a constitutive role in creating the authoritarian capitalist system they are part of (cf. Bunge, 2004).

To date, we know very little about the mechanisms contemporary authoritarian governments use to subject economic actors such as firms to state control. We term this understudied process, that parallels "democratic backsliding" in the political sphere, "economic backsliding." This paper seeks to address this research gap based on interviews with business leaders in Hungary. We seek to explore the question what mechanisms do authoritarian 
governments - and the elite group controlling them - use to erode the frontier between the political and the economic domains?

We consider Hungary to be an "extreme case" in Seawright and Gerring's (2008) sense, regarding the speed at and extent to which the rise of authoritarian capitalism happened. Hungary therefore allows us to explore more clearly the mechanisms underlying the rise of authoritarian capitalism.

Our study contributes further nuance to types of states used in the literature on emerging varieties of capitalism (Fainshmidt et al., 2018; Witt et al., 2017). Our empirical contribution is to identify transformative mechanisms that allowed the government to wrestle back control from private sector actors and move Hungary towards authoritarian capitalism by shifting the boundaries between the public and the private domains. Investigating these often-neglected non-ownership means of political control over the economy and by conceiving of them as constitutive "mechanisms" of the authoritarian- and state capitalist systems, allows us to contribute to the literature by providing a more precise, empirically-grounded definition of authoritarian capitalism.

\section{The "Return of the State" and Business and Society Scholarship}

The ongoing "global shift" in the geography of the world economy from "West" to "East" (Dicken, 2015) and the Global Financial Crisis that started in 2007 have led to a remarkable change in both the discourse and realities of state intervention in the economy (Bremmer, 2008; Kurlantzick, 2016; Musacchio, 2008). The increasing importance of state-owned enterprises as players in the world economy is but one conspicuous sign of this shift (Bruton, Peng, Ahlstrom, Stan, \& Xu, 2015; Cazurra et al., 2014). This "return of the state" came at a time, when most Business and Society scholars had gotten used to analyzing the role of the political in the economy as a "retreat of the state" (Strange, 1996). Thus, since the arrival of 
Thatcherism/Reaganomics in the 1980s, the focus had been on analyzing firms as increasingly important actors in providing public goods and services that states were no longer able or willing to provide on their own (Scherer \& Palazzo 2011; Scherer et al., 2014). The end of Soviet communism reinforced this trend, meaning that little scholarship focused on analyzing the state as an economic actor. Rather, the focus was on its retreat from the economic domain and on the "economization of the political" (Gond et al., 2011: 662; Shamir, 2008). Yet, the return of the state constitutes - to paraphrase Gond et al. (2011) - a "re-politicization of the economic" leading to a different direction in the process of 'socioeconomic hybridization' that they observe.

Three different attempts at "brining the state back in" to account for this shift can be identified in the recent Business and Society literature. Firstly, management scholars have observed and started to theorize the return of the state as an owner of business enterprises (Cazurra et al., 2014; Inoue et al., 2013; Musacchio et al., 2015). From this perspective, any economic system where the state holds a significant stake of stock in companies - either as complete-, majority-, or minority shareholder (Musacchio et al., 2015) - qualifies as "state capitalism" (Kurlantzick, 2016). While important, it has been argued that the narrow focus on the state's ownership function should be broadened to account for other tools interventionist governments use to control economic actors (Situ et al., 2018). Secondly, some studies attempt to capture the specificities of state-dominated economies by applying the VoC approach (Dentchev, Haezendonck, \& van Balen, 2017; Hofman et al., 2017; Witt \& Redding, 2014). Yet, the VoC approach's focus on regulatory institutions and its lack of any theory of the state, leads to a reduction of the role of the state to that of a "rule maker," which sits awkwardly with more direct forms of state intervention in the economy that can be observed in many countries (Gond et al., 2011).Thirdly, some scholars have turned to the tradition of the national businessand national governance systems (Hollingsworth \& Boyer, 1997; Whitley, 2007) as well as 
developmental studies (Doner, Ritchie, \& Slater, 2005; Evans, 1995) to fill the gap in terms of theories of the state. This approach often distinguishes four types of states, namely "regulatory," "welfare states" - that are prevalent in developed economies - and "developmental-" and "predatory states," which prevail in emerging economies (Fainshmidt et al., 2018; Witt et al., 2017). The "predatory" type is "governed by elites who monopolize power [...] so as to generate profits that benefit them rather than society at large" (Carney \& Witt, 2012: 12). As such, it is distinct from the "developmental state," where "a government ministry can have the freedom to plan the economy and look to long-term national interests without having its economic policies disrupted by either corporate-class or working-class short-term or narrow interests" (Carney \& Witt, 2012: 12).

Intriguingly, this useful typology is not leveraged to clarify the concept of "authoritarian capitalism" which has gained considerable traction in the literature (Witt \& Redding, 2014; Situ et al., 2018; Hofman et al., 2017).Thus, Witt \& Redding (2014: 15) characterise China's authoritarian capitalism as "a developmental state with distinct predatory admixtures;" without further explaining how the concepts of authoritarianism, developmentaland predatory state relate to each other.Similarly, Situ et al. (2018: 4) suggest that the Chinese government uses at least three different means to influence companies to achieve its political goals: its influence as a shareholder; its influence as a regulator; and its influence through setting incentives for firms (Situ et al., 2018: 7). For Situ et al., (2018) authoritarian capitalism is a "form of state capitalism" (p.6), which is distinguished from other forms by the fact that the state "uses newer, more sophisticated tools to manage both state-owned and non-stateowned companies" (p.1), namely incentives and regulative influence. However, it is not obvious why these three mechanisms - ownership, regulation, incentives - should qualify as "authoritarian" and how they differ from mechanisms commonly used in (state) capitalist 
countries (Musacchio et al., 2015; Kurlantzick 2016). Indeed, Situ et al. (2018: 9) suggest that because "SOEs play an instrumental role in society" even Norway qualifies as authoritarian capitalism just like China or Singapore. Yet, is authoritarian capitalism a useful description of the Norwegian economy? We would argue that this is only the case if we consider all types of state intervention - even legal ones - as an authoritarian infringement on the private economy. In the next section, we argue that this is too lose a definition of authoritarianism. For tools of state intervention to qualify as "authoritarian," we need to define substantive criteria for what makes state intervention authoritarian or not.

\section{What is Authoritarian about Authoritarian Capitalism?}

Definitions of authoritarian capitalism in recent studies are vague and mostly implicit. Papers using the concept often do not provide any definition of the terms "authoritarian" or "authoritarianism." Rather, scholars appear to simply equate the actual features of the Chinese model of capitalism with the definition of authoritarian capitalism (Witt \& Redding, 2014; Hofman et al., 2017; Situ et al., 2018). Unsurprisingly, this leads these authors to consider authoritarian capitalism as a model sui generis. Thus, Situ et al. (2018: 7) state that China is unique compared to other models of state capitalism "in terms of its linkages and coordination within a party-government-military-economy regime." Yet, a definition of authoritarianism is avoided in favor of equating it with the specific empirical features of the Chinese model (similarly Witt \& Redding, 2014).

We suggest that clearly defining what is "authoritarian" about authoritarian capitalism allows us to turn the concept from a tautological descriptor of China into a conceptual tool that proves useful to understand emerging economies beyond China. Indeed, China is by far not the only emerging economy that bears increasingly authoritarian features. Therefore, we suggest 
that deepening and extending the concept of authoritarian capitalism is a worthwhile step for the study of non-Western countries.

The term "authoritarian" has different meanings. Its basic definition simply means "unquestioning obedience to authority" (Henderson, 1991: 382). A second, substantive meaning defines "authoritarianism" as "personal epistemologies and political structures and practices that are directly threatening to human freedom and dignity" (Henderson, 1991: 382). Such "substantive authoritarianism" is opposed "to the 'liberal' values of tolerance of ambiguity and difference" int that it insists on "obedience to rules, $[\ldots]$ on conformity, and use of coercion and punishment to ensure that obedience" (Henderson, 1991: 382).

Based on this definition, clearly not all state intervention in the economy can be qualified as "authoritarian" and certainly not interventions that are limited to incentivizing, regulating, or exercising the state's legal ownership rights as suggested by Situ et al. (2018). Instead, we suggest, that the term "authoritarian" should be reserved for state intervention that breaks the fundamental liberal norm of the Rule of Law. The RoL, in turn, has many definitions (Ohnesorge, 2007), but can be broadly defined as a norm of equality before the law and the separation of the judiciary from other branches of government. Indeed, the RoL norm implies "that deciding officers [in judicial cases] shall be independent in the full sense, free from external direction by political and administrative superiors in the disposition of individual cases and inwardly free from the influence of personal gain and partisan or popular bias" (Jones 1958 quoted in Ohnesorge, 2007: 101-2). Furthermore, the RoL also requires that the state and its agents subject themselves to the law like any ordinary citizen. As such, it contains a principle of self-limitation whereby the state "acknowledges limits to its own knowledge, capacities and powers" (Chen \& Deakin, 2015: 124). Thus defined, the RoL establishes a double boundary between the private and the public domains: in its classical liberal sense, it implies the protection of the private sphere from undue state interference (Hayek, 1960); yet, it also implies 
that the rule of law protects the political domain from undue interference by private interests (Chen \& Deakin, 2015).

This dual sense of the RoL further implies that not all types of "authoritarian interventionism" are illegal in the strict sense of violating the positive "laws of the land." Indeed, authoritarian regimes can use law very effectively to pursue their oppressive goals (Rajah, 2012). Authoritarian state action therefore needs to be defined beyond the positive law. Here the principle of self-limitation of government power provides an important additional test. Rejecting self-limitation, the ruling elite in authoritarian regimes only accepts the law as long as they control its content and as far as it can be used instrumentally to favor the elite's interests and goals (Müller, 2017). Beyond that, they do not subject themselves to the RoL and do not respect the "checks and balances" that were put in place to guarantee it. Institutional reforms to subject the judiciary power to the executive power of the government are indeed a hallmark of contemporary authoritarian regimes (Müller, 2017).

Defining authoritarianism as erosion of the two boundaries between the private and the public that the RoL establishes, suggests a second key feature of authoritarianism confirmed by many studies of modern authoritarianism, namely, the colonization of the state by elite groups - or "clans" - which use the state apparatus to pursue their private interests rather than public interests (Ledeneva, 2013; Magyar, 2016; Müller, 2017; Wedel, 2003).

Based on these definitions, we conceptualize the shift from a regulatory state to state capitalism and to authoritarian capitalism as a process, whereby the political domain is further extended into the economic realm than what the ideal-typical neoliberal "regulatory state" that "steers but doesn't row" (Osborne \& Gaebler, 1992) - would consider optimal; thus challenging what Aßländer and Curbach (2017) consider the ideal governing principle of statebusiness relationships, namely "subsidiarity." 
In both cases, the state becomes an economic actor in its own right, who extends its function beyond the regulatory one. Yet, contrary to the case of state capitalism, in the case of authoritarian capitalism this shift of the boundary between the political and the economic happens in a way that disregards the liberal-democratic principles of the Rule of Law (RoL) and of the self-limitation of the state (Chen \& Deakin, 2015, p. 124), violating hence some private actors' fundamental rights. ${ }^{1}$ Moreover, a second erosion of the political-economic divide takes place in authoritarian capitalism through the increasing identification of the state's interests with the private interests of the governing elite, which sets apart authoritarian capitalism from state capitalism.

Our conceptual clarifications and narrower definition of authoritarian capitalism also implies that, contrary to Situ et al.'s (2018) definition, "tools" of state intervention such as owning, regulating, and incentivizing cannot be considered as hallmarks of authoritarian capitalism per se. Rather, it is the ways in which they are used - namely in violation of the RoL - that turn them from tools of "state capitalism" into instruments of authoritarian capitalism (see table 1). Indeed, we would argue that rather than talking about "tools" in this context, the ways in which the state exercises its control over the economy should be considered as a "social mechanism" defined as "one of the processes in a concrete system that makes it what it is" (Bunge, 2004, p. 182; also Hedstrom \& Ylikoski, 2010). The "tools" of state control over the economy are precisely such mechanisms that - in a constitutive way - make "authoritarian capitalism" what it is.

\footnotetext{
${ }^{1}$ These are not necessarily equivalent to legal and constitutional rights, because an authoritarian state may very well draft laws and constitutions that precisely aim at excluding certain parts of the population from having their fundamental rights protected (cf. Müller, 2017). In this sense, a regime can qualify as authoritarian even if it follows the rule of law in the narrow sense, which only implies that the positive law is applied equally to all subjects of the law. In a situation where the government has the power to freely change laws and even the constitution, the principle of self-limitation of government power - which must include the respect of fundamental rights - becomes a crucial additional barrier to authoritarianism.
} 
Table 1: State capitalism versus authoritarian capitalism

\begin{tabular}{|l|l|l|}
\hline & State capitalism & Authoritarian capitalism \\
\hline $\begin{array}{l}\text { Public } \rightarrow \text { Private Divide } \\
\left(\mathbf{1}^{\text {st }} \text { boundary }\right)\end{array}$ & $\begin{array}{l}\text { Expansion of political into } \\
\text { economic beyond regulatory } \\
\text { state's "subsidiarity } \\
\text { principle". State becomes } \\
\text { economic actor. }\end{array}$ & $\begin{array}{l}\text { Expansion of political into } \\
\text { economic beyond regulatory } \\
\text { state's "subsidiarity } \\
\text { principle". State becomes } \\
\text { economic actor. }\end{array}$ \\
\hline $\begin{array}{l}\text { Private } \rightarrow \text { Public Divide } \\
\left(\mathbf{2}^{\text {nd }} \text { boundary) }\right.\end{array}$ & $\begin{array}{l}\text { Identification of state interest } \\
\text { with notion of "public } \\
\text { interest" and "collective } \\
\text { goods." Relative autonomy } \\
\text { of state apparatus from } \\
\text { particularistic interests. }\end{array}$ & $\begin{array}{l}\text { Identification of state interest } \\
\text { governing elite group. } \\
\text { Colonization of state } \\
\text { apparatus by elite interests. }\end{array}$ \\
\hline
\end{tabular}

We know very little about such mechanisms that allow governments to shift the boundary between the public and the private and how this alters state-business relationships. This paper seeks to start covering this gap by investigating the mechanisms the Hungarian government of Viktor Orbán has used since 2010 in order to "take back control" over the economy from the business elite.

\section{Data and Method}

\section{The case context}

The context of post-socialist economies in East Central Europe (ECE) - i.e. Hungary, Poland, Slovakia, and the Czech Republic - constitutes an ideal setting to study the "politicization of the economy" and the mechanisms by which an authoritarian government extends the public domain into the economic one in the interest of the ruling elite. For more than a decade after the fall of communism, these countries were amongst the most advanced in their transition towards a Western-style capitalism. Yet, all ECE countries recently experienced a dramatic change in direction in their transition, away from the Western ideal of a liberal-democratic 
market economy towards a more state-dominated and less democratic model (Greskovits, 2015; Sedelmeier, 2014).

In Hungary, since the 2010 elections, the conservative coalition of Fidesz and its junior partner, the Christian Democratic People's Party (KDNP), have held more than two-thirds of the seats in the parliament (Kovács, 2015). Following the April 2014 parliamentary elections, the Fidesz-KDNP coalition held 133 of 199 seats and in addition won the European Parliament and local elections during the same year (Greskovits, 2015; Kovács, 2015). The most recent elections in the spring of 2018 have confirmed Fidesz's dominant position in the country's political system. On the national voting list, Fidesz secured more than 49 percent of the vote, with some 2.6 million voting for the party and its Christian Democratic allies; nearly as much as the seven largest opposition parties combined. Securing a two-thirds majority in Parliament, the party has a free hand to pursue in-depth legal and constitutional changes that have already given it firm control over courts and other state institutions (Santora and Bienvenu, 2018).

Using its supermajority in parliament, the ruling coalition has systematically engaged in actions that undermined democratic institutions (Freedomhouse, 2017; Greskovits, 2015; Kovács, 2015; Sallai, 2014), curbed judicial independence, and clamped down on the independent media (Tait, 2016). These well-documented actions by the Hungarian government have been interpreted by political scientist and sociologists as signs of "democratic backsliding" (Ekiert, 2012; Sedelmeier, 2014; Bandelj et al., 2015; Greskovits, 2015) or a “democratic U-turn” (Kornai, 2015a).

\section{Political and economic backsliding}

"Backsliding" is defined as "destabilization or even a reversal in the direction of democratic development" and "is usually traced to the radicalization of sizeable groups within the remaining active citizenry, and the weakening loyalty of political elites to democratic principles" (Greskovits, 2015: 28). More concretely, "democratic backsliding" in Hungary and 
elsewhere involved various simultaneous processes including "softening up the legal and procedural constraints of legislation and government; far reaching centralization within the units of public administration; increasing exposure of civil servants to political pressures; stripping the parliamentary opposition off its remaining opportunities to influence political decisions; serious restrictions of media freedom; and the repeated modification of the electoral law in favor of the incumbent" (Greskovits, 2015: 34).

Yet, the process of backsliding has not just affected the political sphere - in terms of the undermining of democracy and pluralism -, but also the economic sphere, bringing these countries closer to a model of "authoritarian capitalism." Indeed, while the first phase of transition after the end of socialism has led to the emergence of private business sector through privatizations and the establishment of new firms (Martin, 2002), we have recently seen a return of the state as an economic actor in its own right. Our empirical analysis attempts to investigate the nature of mechanisms used by the government in this process of "economic backsliding" that leads to authoritarian capitalism.

\section{Research design}

In order to explore the nature of "authoritarian capitalism" we focused on Hungary as a single country case. We selected Hungary as a critical- or revelatory case, because it is arguably one of the most extreme examples of "backsliding" and hence proves particularly useful in revealing the mechanisms at work. Thus, in 2005, the EBRD (2005) designated Hungary as the most advanced country in its transition towards western-style liberal capitalism. Ten years later, Hungary is essentially controlled by a single party (Sedelmeier, 2014; Greskovits, 2015) and constitutes an extreme case of 'strong man politics' (Lendvai, 2017). Extreme cases help us explore patterns that may not be easily recognizable in an average-, or typical case (Seawright \& Gerring, 2008). 


\section{Data and analysis}

Our empirical analysis is based on 60 semi-structured interviews conducted between 2009 and 2017 (See Table 2). We chose to carry out semi-structured in-depth interviews, because they constitute an insightful method for exploring the "often nuanced causal factors of specific managerial action" (Lawton et al., 2013: 231).

Regarding our sampling strategy, given the sensitive nature of the research topic we relied on personal contacts to secure the interviews. After having obtained a first set of interviews, we used a 'snow-ball' sampling approach based on our interviewees' recommendations and introductions. We targeted foreign and domestic firms in Hungary, because we aimed to constitute a sample comprized of all categories of companies commonly distinguished in the post-socialism literature, namely privatized incumbent firms, foreign new entrants, and domestic new entrants (e.g. Martin, 2008). We used categorical sampling by selecting participants from a wide variety of sectors and types of companies (see table 2).

Table 2: Respondents by sector

\begin{tabular}{|l|l|l|r|}
\hline Informant's sector & $\begin{array}{l}\text { Nype of interviewee } \\
\text { (number of interviews) }\end{array}$ & $\begin{array}{l}\text { Yumber } \\
\text { of Total } \\
\text { interviews } \\
\text { interviews in that year) } \\
\text { sector }\end{array}$ \\
\hline Banking & CEO (4), Vice-CEO (2) & $2012(4), 2016(2)$ & 6 \\
\hline Construction & $\begin{array}{l}\text { Chair (2), Director (2), } \\
\text { CEO (1) }\end{array}$ & $2011(3), 2012(1), 2016(1)$ & 5 \\
\hline Energy & CEO (1), Director (5) & $2011(4), 2013(1), 2015(1)$ & 6 \\
\hline ICT & CEO (4), Director (5) & $2009(2), 2011(3), 2012(1)$, & 10 \\
\hline Manufacturing & $\begin{array}{l}\text { CEO (5), Vice-CEO (1), } \\
\text { Director (2) }\end{array}$ & $\begin{array}{l}2009(1), 2011(2), 2012(1), \\
2015(1), 2016(2), 2017(1)\end{array}$ \\
\hline Telecommunication & CEO (1), Vice-CEO (1) & $2015(1), 2016(1)$ & 2 \\
\hline
\end{tabular}




\begin{tabular}{|l|l|l|r|} 
Retail & Director (4) & $2011(1), 2012(1), 2016(2)$ & 4 \\
\hline Wholesale & CEO (2) & $2012(1), 2017(1)$ & 2 \\
\hline $\begin{array}{l}\text { All other sectors: } \\
\text { tobacco, tourism, } \\
\text { consulting, } \\
\text { advertising, } \\
\text { beverages }\end{array}$ & CEO (1), Director (4) & $\begin{array}{l}2009(1), 2012(1), 2013(1), \\
2016(1), 2017(1)\end{array}$ & 5 \\
\hline NGOs & $\begin{array}{l}\text { Secretary General (4), } \\
\text { Director (7) }\end{array}$ & $\begin{array}{l}2011(4), 2012(2), 2016(2), \\
2017(3)\end{array}$ \\
\hline $\begin{array}{l}\text { Other } \\
\text { Total number of } \\
\text { interviews }\end{array}$ & $\begin{array}{l}\text { Journalist (1), Political } \\
\text { advisor (1) }\end{array}$ & $2011(1), 2017(1)$ & 2 \\
\hline
\end{tabular}

The final sample included 22 interviews with top managers (CEOs, vice-CEOs, board members, heads of business units) of Hungarian firms and 25 interviews with CEOs and Public Affairs directors of local subsidiaries of multinational companies (MNCs). Among the multinational subsidiaries we had companies with headquarters in the US (6), France (4), Germany (3), UK (1), Switzerland (1), Denmark (1), Italy (1) and the Netherlands (1). Out of the 22 interviews with Hungarian firms, 8 were state-owned while 14 were privately owned businesses - out of which 2 were privatized incumbent firms, and 12 domestic new entrants.

Table 3: type of organizations in sample

\begin{tabular}{|l|r|}
\hline Type of organization & Number of interviews \\
\hline MNE & 25 \\
\hline Domestic & 22 \\
\hline NGO & 13 \\
\hline Total number of interviews & 60 \\
\hline $\begin{array}{l}\text { Total number of printed and online } \\
\text { news articles and reports }\end{array}$ & 71 \\
\hline
\end{tabular}


To limit bias in our interview data, we used different data collection approaches for increasing accuracy in retrospective research (Golden, 1992; Miller et al., 1997). We included additional interviewees from the context of the case (associations, chambers of commerce, trade unions, and NGOs). We used secondary data to verify interviewees' factual claims including information available on corporate websites, journalistic sources (including the Hungarian economic weekly HVG, Bloomberg.com, the Telegraph, Reuters.com, EurActiv, and The Economist), and reports by NGOs such as atlatszo.hu and Transparency International.

Our interviews ranged from 45 to 90 minutes in duration. We carried out data collection and data analysis in parallel through an iterative process in order to develop our understanding of the processes and to reflect on the emerging findings.

Interviews were conducted in English and Hungarian and were transcribed in English. When translating the interviews, we followed the notion that the "process of translation itself can be treated as data and the source of contextual insights and conceptual understanding" (Chidlow et al., 2014: 23). Although these insights are almost never reported in studies (Chidlow et al., 2014), we attempted to analyze and reflect on the nuances that were provided by insights in conversations that are not technically "translatable."

After the translation and transcription of interviews we analyzed the data by identifying initial concepts and grouping them into first-order concepts (categories), relying on respondents' quotes and terms. We used axial coding to create second-order concept by "refining and differentiating concepts" (Böhm, 2004: 271). At this stage, we drew on existing literature that has identified techniques and mechanisms of authoritarian capitalism. These include in the economic realm ownership, regulation, and incentives (Situ et al., 2018). In the realm, of authoritarian politics, the extant literature has identified the centralization of the state apparatus, the exposure of the public administration to political pressures, stripping political opponents off their opportunities to influence political decisions (Greskovits, 2015), the 
reduction of political pluralism through the authoritarian use of legislative and constitutional change, leading ultimately to the 'colonization' of the state by an elite group in pursuit of their private interests (e.g. Müller, 2017: 44). All these mechanisms of "democratic backsliding" have their equivalent in the economic sphere, which allow us to identify relevant second-order concepts. Finally, we gathered similar second-order concepts into aggregate dimensions to build the basis of the framework that emerged. Once we had the draft aggregate dimensions we went back to our theoretical constructs and carried out an iteration process between our newly emerging framework based on our data and the theory (Gioia et al., 2012). We used NVivo 12 software for our data analysis and followed the "Gioia method" (Gioia et al., 2012), to identify the four aggregates that represent four mechanisms of "economic backsliding" that lead to authoritarian capitalism.

\section{Empirical Findings: From political to economic backsliding}

This section presents our empirical findings from the in-depth interviews with a view to deepen our understanding of "authoritarian capitalism". We focus on the economic rather than the political sphere and analyze the mechanisms the Orbán Government used in bringing about "economic backsliding." Our data shows that for the economy, "backsliding" has meant a dual shift in the boundary between the public and the private domains: Firstly, the state has once again become an active economic player who controls the economy and even competes with private actors; secondly, the state's interests have become increasingly undistinguishable from the private interests of the governing elite. We find evidence for four different mechanisms through which this has been achieved: 1 . The creation of state dependence of private actors, 2 . The reduction of economic pluralism to align economic actors' interests with the political elite's interests 3 . The state being used as a tool to extract private rents, and 4 . authoritarian shareholding (See Figure 1). 


\section{Figure 1: Data structure}

First order concepts
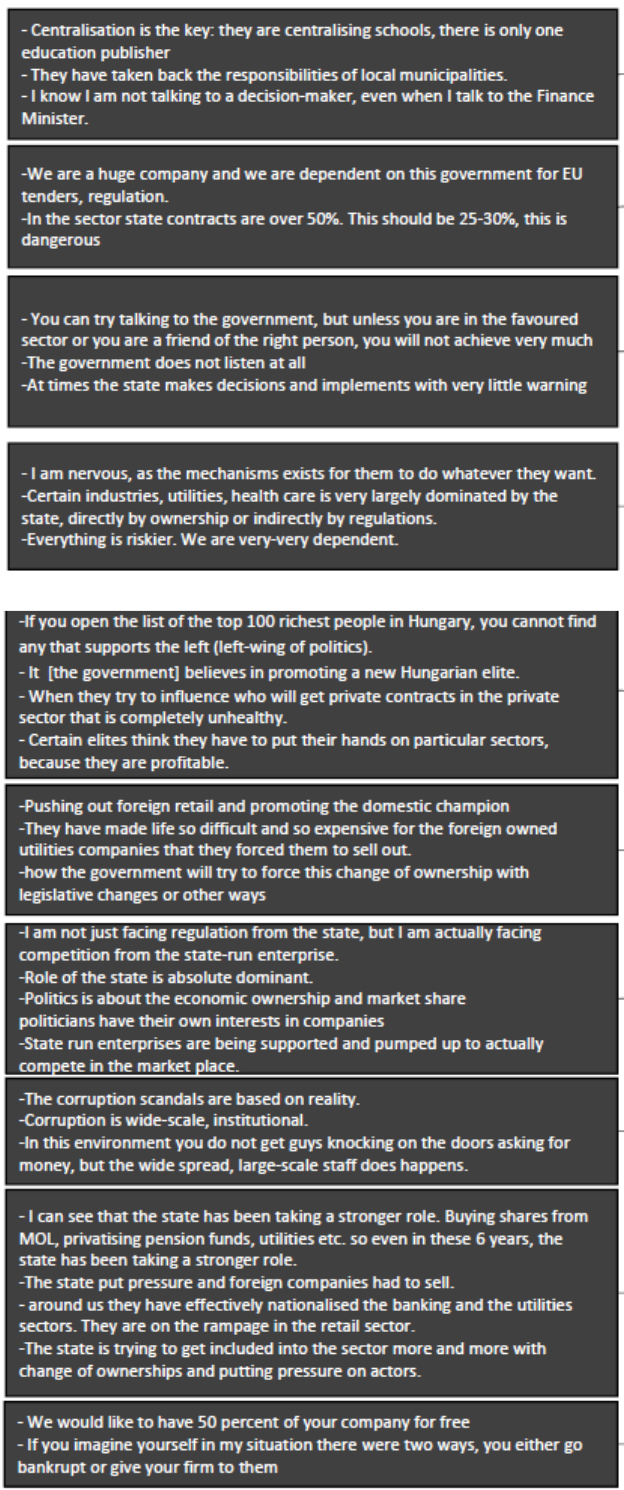

Second order concepts
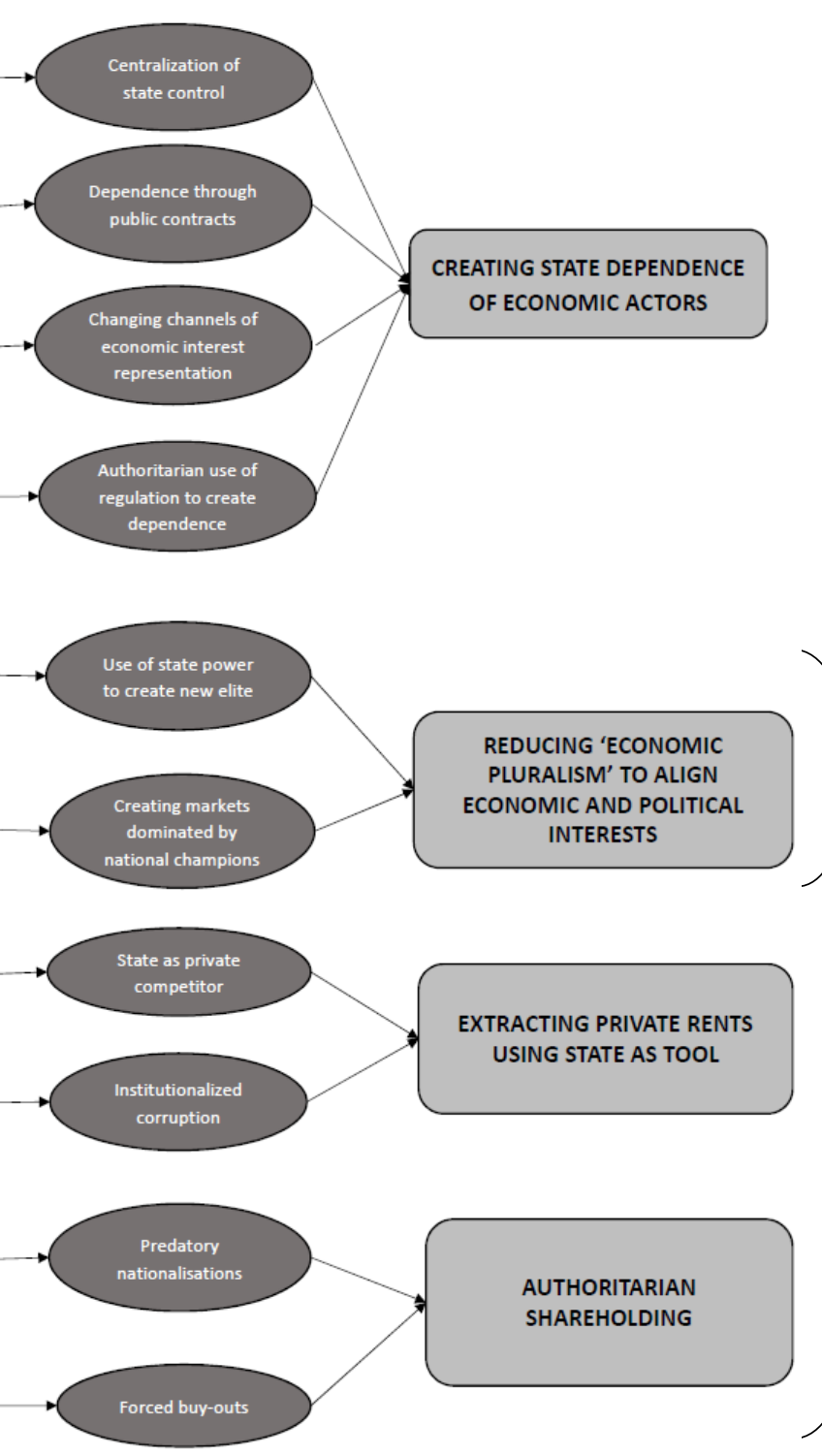

AUTHORITARIAN SHAREHOLDING
EXTRACTING PRIVATE RENTS USING STATE AS TOOL
Aggregates

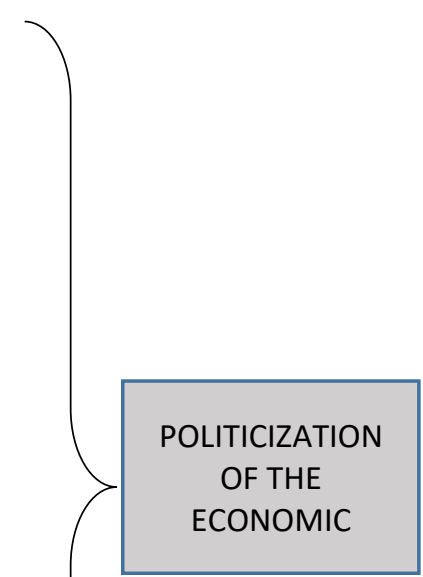

\section{Creating state-dependent economic actors}

The first mechanism of the "politicization of the economic" used by the Hungarian government consists in making economic actors increasingly dependent on the state for their survival. Four 
interrelated processes relate to this first mechanism: the centralization of state control over politics, the economy, and civil society; making private actors dependent on public contracts for income; changing - and restricting - the official channels of economic interest representation; and using laws and regulation with the sole purpose of creating dependence. In the following we will illustrate these processes through our interview quotes.

Centralization of state control. Since 2010, Fidesz has used its control over parliament to 'create a system based on the monopolization of the most important elements of political power' (Bozóki, 2011: 650). We call this process the centralization of state control. The government introduced legal changes that centralized decision-making at various levels of the state bureaucracy (Hajnal and Rosta, 2014, Kornai, 2015b). The increasing centralization of the state structure was accompanied by the appointment of people close to Fidesz to key state positions. This evolution considerably weakened the independence of state institutions, which previously played important roles in counterbalancing the government's powers (Transparency 2012_b). Some of the institutions affected by party-related appointments were the State Audit Office, the Prosecutor's Office, the Hungarian Financial Supervisory Authority, and the Budgetary Council (Bozóki, 2011: 652). Most recently, in December 2018, the Orbán government introduced a 'parallel court system' that creates full executive control over the judiciary (Novak and Kingsley, 2018). These courts will have jurisdiction over all cases relating to 'public administration', including electoral law, corruption, and the right to protest. Under the new regime, the minister of justice will control the hiring and promotion of all judges working in the parallel courts. Consequently, "Hungary's existing judiciary will continue to work with a reduced mandate, and with no oversight of the parallel court system, known as the administrative courts" (Novak and Kingsley, 2018:1).

Centralization of governmental control over the state bureaucracy also involved political appointments to key public positions. Thus, a former Fidesz member of the parliament has become President of the Media Authority, while the spouse of a prominent Fidesz Member of European Parliament (MEP) became Head of the National Judicial Office (Bozóki, 2011). The Constitutional Court's jurisdiction has been reduced substantially when the justices 
appointed by Fidesz-KDNP obtained a majority in the court in 2013 (Kovács, 2015: 273). Newly introduced legislation made it possible to dismiss public officials without cause, which in turn made "the cleansing of the entire government apparatus" possible (Bozóki 2011: 652). These changes violate if not the letter, so at least the spirit of the Civil Service Act of 1992, which according to Negoita (2006: 225) "separated central policy from service delivery functions and clearly distinguished between political appointees and professional career employees." Indeed, one key element of the rise of Orbán's authoritarian capitalism in Hungary is the undermining of the previously - for post-socialist standards - exemplary technocratic and meritocratic bureaucracy (Negoita, 2006) and the separation of powers. The elimination of a meritocratic civil service and the worsening employment/retirement conditions of public servants (Hajnal and Rosta, 2014) have created an atmosphere in which public administrators became servile to the governing elite rather than wedded to professional standards.

Our respondents' perception of the declining autonomy of the state apparatus from Fidesz shows the impact of this trend on the economy. From the company's perspective, the main change implied that civil servants now act mainly following political and private interests, rather than public ones.

"[P]ublic administrators are very much threatened - today they can be fired without a reason. It is not necessary [for Fidesz politicians] to even give them a mandate to do this or that, because they are so scared that they want to please politicians" (Respondent at Hungarian NGO1).

Consequently, public sector career paths have dramatically changed. Instead of a meritocratic, long-term career progression, based on formal competences and experience, political loyalties and uncertainty now prevail: 
"I know somebody, who used to work for a ministry two years ago, and since then he cannot find a job. Just because he worked there at the time of the other government" (Respondent at Subsidiary17).

The job insecurity for civil servants and demand for political loyalty is combined with an increasing centralization of decision-making in the hands of the inner circles of power. Even top-level civil servants and ministers' decision-making abilities are limited, because many powers are concentrated in the PM's hands. A respondent stated that:

"I believe that today the power is in one hand - Orbán’s. Not even his ministers know which way to go. So, this adds to the uncertainty. People do not know what they can or cannot do. People cannot operate" (Respondent at Local15).

Dependence through public contracts. Our interviews also suggest that the private sector has become increasingly dependent on income stemming from the state. Firms operating in different sectors explained that the state has become dominant as "a large customer" through "big investment projects," making public contracts essential for survival, including in marketing, services, and construction (Subsidiary04; Local04). Respondents highlighted that the state has become a "more and more dominant player in the economy," however not only as a customer, but also in "distribution and in ownership" (Subsidiary04).

Changing channels of economic interest representation. Centralization and powerlessness were also mentioned when respondents spoke about the changing channels of economic interest representation since 2010, which parallels the removal of opportunities for political opponents in Parliament to influence decision-making (Greskovits, 2015). Many argued that traditional interest groups such as chambers of commerce or industrial associations no longer have a voice in Hungary. Some even stated that they have "zero impact" as the government "does not listened at all" (Subsidiary01). Others, representing industry interests, cited examples of how 
officials at Ministries were not allowed to meet them until they got clearance from the top: "When the crisis tax was introduced a Secretary of State met us - in our role as representatives of the trade association - in the Ministry of Economy and he said to us that he had been 'authorized' to meet us" (Subsidiary08). This indicates how centralization leads to reduced autonomy of public officials and a close central political control even over high-ranking public official.

Respondents claimed that decision-makers at public bodies and state offices are powerless, as the final decisions depend on the PM's approval: "There are 2-3 people that influence the prime minister, but even they do not make the decisions, ultimately the prime ministers make the decisions" (Subsidiary01). Some argued that there was somewhat more openness during the second government in 2014-18 when companies were more listened to, although "not heard" (Subsidiary02) as there were no "public consultations before legislative changes" (Subsidiary08). To achieve this, the Orbán administration institutionalized a hitherto rarely used process in political decision-making: proposing legislation through MPs' motions. The majority of proposals submitted to the Parliament in 2010 were MPs' motions (Transparency 2012). When a legislative proposal is introduced by individual MPs, no ministerial consultation procedures or the involvement of the government is required. In this environment businesses feel that "in Hungary it is not worth to represent interests because today in the Parliament a 'voting machine' operates" (Local09).

Authoritarian use of regulation. A further mechanism by which the Orbán government shifts the boundary between the public and private, is the authoritarian use of law and regulations by introducing laws and regulations that are purely aimed at creating dependence of economic actors on the state. The Orbán government has extensively used legal- and tax reforms to change the "playing field" in formally legal ways that many existing companies 
cannot cope with. Thus, various legal changes forced existing companies in different sectors out of business and paved the way for the entry of new, politically-connected companies (cf. Kovács, 2015). Targeted sectors were mainly those focused on the domestic market in the services sector, because the government considered foreign investment in these areas "bad FDI" (Sass, 2017: 6).

Given the formal legality of these types of state intervention in the economy, one could expect that companies can also use legal means to protect themselves through law suits or appeals to the Constitutional Court. However, this is where the authorities' use of legal means and respect of the RoL ends. Thus, an interviewee from a large Hungarian company described the situation where the company was owed money by a SOE and the state authorities intervened to settle the conflict:

"I was ordered to go to the Ministry to see the Secretary of State [...]. He was very rude and told me that whatever will happen he will sit in his chair for the next eight years and therefore he advises me not to push it, because obviously he will make me feel the weight of my decision [...]. There were five people there [...]" (Respondent at Local10).

This type of intimidating and arbitrary state intervention to prevent companies from using the legal means at their disposal has created a general apprehension among the business elite of the state authorities who do not respect the principle of self-limitation of state power any longer:

"Today, there is a fear from central authority in people's blood; a fear that they can take away anything, do anything." (Respondent at Local15).

"You make decisions that you would not make in a stable environment. I give work to this person,...money to that person... Just leave me alone!... CEOs are kept in fear" (Respondent at Local15). 
This authoritarian use of law constitutes a major difference between state capitalism and authoritarian capitalism. While in state capitalism the government may intervene extensively in the economy, it does so while respecting basic principles of the RoL, while the authoritarian use of law and regulation implies that formally legal intervention is backed up by pure threat and intimidation that violates the RoL.

2. Reducing 'Economic Pluralism' to align economic actors' interests with the governing elite's

Using legal and constitutional changes to reduce political pluralism is a hallmark technique used by authoritarian governments to increase their power (Müller, 2017). An equivalent technique is applied to the economic sphere to reduce "economic pluralism" by creating an economic elite whose interests are aligned with the political elite. Indeed, the Orbán government has used the state apparatus to align the interests of parts of the economic elite with the interest of the governing elite group, by transferring state- and private assets to supportive actors, while eliminating others; creating thus a new economic elite and aligning the economic and political elite's interests.

Creating a new elite. The reshaping of the retail sector provides an example of how the government redistributes state assets to create a new elite. A "special tax" was introduced in 2010 with a retroactive effect. The tax required all retailers operating in Hungary with annual revenue over 500 million HUF (\$2.2 million) to pay a special tax on their consolidated revenues. In February 2014 the European Court of Justice (ECJ) ruled that the special retail tax puts companies from other EU member states at a competitive disadvantage as many of the largest retail groups who were exposed to the highest rate were foreign companies, while the Hungarian retailers were smaller companies paying a much lower rate (Gulyas, 2014). In reaction to the ruling, in December 2015, the parliament passed a series of laws that directly targeted international retail chains operating in Hungary, requiring non-family-owned retailers 
of a certain size to remain closed on Sundays, and stores to close if they reported losses for two consecutive years. The combination of these rules put multinational corporations at a disadvantage compared to Hungarian competitors (Budapestbeacon.com, 2016). According to our interviewees, the goal of these changes was to reshape the ownership of firms in key domestically orientated sectors in favor of Hungarian owners:

\footnotetext{
"Sectoral taxes, financial crisis tax, legislation on Sunday opening times, they all served the goal to bring into position Hungarian chains and force the change of ownership in the sector. This has not happened yet. We feel that this goal is still there, and we constantly have to pay attention to see how the government will try to force this change of ownership with legislative changes or other ways, so in this respect the role of the state is absolute dominant." (Respondent at Subsidiary07).
}

The ruling political elite thus directly influences companies' position in the market, restructures industries, and appoints or eliminates the dominant players in the Hungarian economy (Kovacs, 2015). Beyond pecuniary interests of the ruling clan, these changes also had the more profound effect of reshaping the Hungarian economic elite, creating a group within it whose interests are directly aligned with the governing political elite.

One interviewee stated:

"As a result of this economic policy, a new oligarch circle has been created who took over a few sectors, like retail, media and construction.” (Respondent at Subsidiary15).

Creating dominant national champions. A related technique of reshaping industries to reduce economic pluralism consists in creating a market dominated by chosen national champions while driving out foreign actors. One example is the 2013 re-regulation of the tobacco market. The cabinet introduced a law that guaranteed state monopoly for retail sales of tobacco products 
(Econews, 2012), withdrew all previously existing retail licenses, and distributed a more limited number, mostly to people close to prominent Fidesz members (Kovács, 2015, Nagy and Szabó, 2013). This step drastically disadvantaged major multinational tobacco companies and small family-owned retail shops. In December 2014, the government restricted the wholesale market, stipulating that the newly licensed retailers will only be permitted to purchase from state-owned wholesale corporations or those that the state contracted (Kovács, 2015: 287). Due to the monopolization of tobacco products, the number of retail outlets dropped sharply from 42,000 to 5,415 (JM, 2013, Piac és Profit, 2013). It soon became clear that the new legislation originally was aimed to create a monopoly for Continental Zrt., a Fidesz-related tobacco manufacturer (Batka 2012), whose employees and their family members have indeed won many of the new concessions (HVG 2013; Nagy and Szabó 2013). Investigatory journalists also claimed that the tobacco act was written on the computer of Continental's CEO, a close friend of Fidesz's party leader, who officially submitted the proposal to the Parliament (HVG 2013). This case illustrates how the government re-nationalises sectors temporarily by creating state monopolies through legal means before re-privatising them by reallocating property to its own supporters (Magyar 2013: 265), thus creating a new elite whose interests are aligned with the political elites' private interests.

One of our respondents commented:

"[T]hey are killing the economy with indirect tools, like tobacco legislation. They turn the retail trade of tobacco products into a state monopoly; and then they turn the retail of alcohol and lotto sales into a state monopoly as well. So, all private tobacco firms, alcohol firms, and Toto-lotto firms go bankrupt. This is how they create a market for their own economic empire" (Respondent at Local17).

The tobacco case also illustrates the authoritarian nature of the process of creating state monopolies and national champions in the sense that the procedure to achieve this goal 
systematically violated the RoL. Thus, when the government introduced the monopolization of tobacco retail sales, amendments were introduced after the closing date for applications for retail licenses and the concession was awarded without an open tender process (OECD, 2016). Furthermore the 2015 Freedom of Information Act abolished the government obligation to share information and data used in the decision-making process (OECD, 2016).

\section{The state as a tool for private rent extraction}

Our theoretical framework implies that both state capitalism and authoritarian capitalism differ from regulatory capitalism in the sense that the state becomes an economic actor in its own right. Yet, the key difference between state capitalism and authoritarian capitalism is that in the former case the state has a certain degree of autonomy vis-à-vis private interests and at least partially pursues public goals (Carney \& Witt, 2012), while in the latter case the state is itself being colonized by the ruling elite's private interests (Muller, 2017). Two concepts emerging from our data capture the state's loss of autonomy vis-à-vis the private sphere directly, namely changes in the nature of corruption and the state becoming a competitor for private firms.

Institutionalized corruption. Our respondents consistently referred to changes in the nature of corruption under the Orbán government. Thus, rather than petty corruption of lower level bureaucrats, corruption has become "institutionalized" since 2010 in the sense that it is now involving the state authorities themselves, rather than individual public officials within them. "They threaten the company. By for example sending the tax office out for control. They can always find something. They can make your life hard if you do not cooperate. We want to live in this country, but if you want to live here, they can make your life a struggle " (Respondent at Local15). 
In other words, rather than the "bottom up" corruption of the early post-socialist period, corruption is now "top down" and institutionalized in the state bureaucracy (cf. Kang, 2002). This trend directly erodes the boundary between the public and the private domains, leading to the blurring of public and private interests. One interviewee stated: "The situation when the economic and political life is separated from each other and have a corrupt relationship - is over. This is not the case anymore. Today the two are the same. Nobody can enter this system" (Respondent at Local17).

The state as competitor. A second concept related to this mechanism is the state becoming an economic competitor for private firms. Various interviewees argue that State-Owned Enterprises are increasingly supported by the government to gain an advantage over non-Fidesz affiliated private firms (see Figure 1). Yet, while SOE competition is a feature of state capitalism too, under authoritarian capitalism, the state has become a tool for the elite controlling it. Thus: "In my view, it is not the state that competes with firms, but rather individuals who compete through the use of the state's infrastructure." (Respondent at Local10).

\section{Authoritarian shareholding}

Contrary to Situ et al. (2018), our more restrictive conceptualization of authoritarian capitalism implies that shareholding by the state per se cannot be seen as a mechanism of authoritarian capitalism. It becomes part of the authoritarian capitalist repertoire only if the RoL is violated in the process of acquisition or when shareholdings are used in the pursuit of the governing elite's purely private interests. We call this mechanism 'authoritarian shareholding'. Based on the Hungarian case we identify to related concepts "predatory nationalizations" and "forced buy-outs." 
Predatory nationalizations. After the initial wave of privatizations in the 1990s, predatory nationalizations started in 2010 when the government also nationalized the private pillar of the mandatory pension system (Adam and Simonovits, 2017). The first company targeted by re-nationalization was MAL Zrt., one of the largest aluminum manufacturers in Hungary. When a red sludge reservoir burst and caused serious environmental damage and casualties (Dunai, 2010), the government took the opportunity to have Parliament nationalize MAL just days after the disaster (Day 2010). In 2011, the government suspended state control over MAL, but the regional environmental agency imposed a HUF 135 billion fine on the company (Mihályi, 2015).

Renationalization measures were often helped by the authoritarian use of regulation discussed above and hit not just domestic firms. One interviewee at a foreign subsidiary stated:

\footnotetext{
"They have made life so difficult and so expensive for the foreign-owned utilities companies that they forced them to sell out. Regulating gas and electricity retail prices down to loss making levels, instituting utility tax [...]. You did not see a wave of Venezuela style nationalization, but measures were taken to seriously reduce value of these companies and then they [could buy them up]. That's what happened in the utilities and bank industries.” (Respondent at Subsidiary01).
}

State-ownership expanded significantly in sectors such as energy, banking, public works, transportation, the media, and advertising (Kornai, 2015a). Thus, in 2012 the government declared its plans to re-nationalize the gas sector by buying back E-On's Hungarian gas business (EurActiv, 2012, Than, 2012). It also bought back 21.2 percent of the 
previously privatized national oil and gas corporation MOL from the Russian oil company Surgutneftegas (BBJ, 2012). By 2016 energy retailing had become a government-owned monopoly as the state has bought private electricity and gas retailers through the state-owned Hungarian Development Bank (MFB) and the Hungarian Electricity Company (MVM). Through these transactions the state has bought subsidiaries of the German E.On and RWE and the French GDF and EDF (Kovács, 2015).

Some of the re-nationalizations were first initiated by the previous, Socialist-led government (Mihályi, 2015). However, under the Orbán government, these re-nationalizations changed in nature and increasingly became predatory. Indeed, (re)nationalizations are not necessarily illegitimate means of state intervention in the economy per se and may very well have a positive impact on economic development in some cases. Thus, in many state capitalist regimes nationalizations are often carried out "for the benefit of the nation" (Ma, 2011) and governments can pick winners to promote growth (Evans, 1995). What makes the renationalizations in Hungary part of authoritarian capitalism is that they are - despite the nationalistic anti-FDI rhetoric surrounding them and despite the government compensating the previous owners quite generously (Mihályi 2015:1) - not part of a national developmental strategy, but rather a predatory one that serves the governing elite to extend their power over the economy and enrich its members. Indeed, evidence suggests that government officials have private interests in economic restructuring (Peth 2011; atlatszo.hu 2012) and many friends and family members have become extremely rich, in some cases among the richest in the country, due to re-nationalizations (Buckley and Byrne, 2017).

One respondent described the strategy in the following terms:

"The government nationalized gas utility companies. [...] So politically the message is very good: we have chased out profit-hungry foreign multinationals. 
They [the state] take over these utility services, then technological standards will erode, and the government will say we need to improve the technological quality, they will improve it from taxpayers' money...oh no, before they start to improve, they will assign who will be the future buyers... their mates. Then they will sign the contract with them and afterwards the state will improve the technological quality of the companies for several billion HUFs and then these firms will be transferred into private hands close to the government. And then sooner or later they will try to sell them again to foreign multinationals." (Respondent at Subsidiary11).

Forced buy-outs. A second aspect of the "authoritarian shareholding" mechanisms can be called forced buy-outs (FBOs). FBOs resemble what is known in the Russian case as illegal corporate raiding (reyderstvo) (Rochlitz, 2014), but is used in Hungary more actively by actors close to the government. Our respondents referred to many concrete cases of FBOs. Indeed, since 2010 "private property has become the target of frequent legal, economic and ideological attacks" (Kornai, 2015a: 6).

Our interviews suggest that FBOs generally are carried out by Fidesz-related individuals approaching the owners of private companies and "persuading" them to "sell" their ownership rights, often without payment. Our respondents claimed that when owners refuse to cooperate and sell the company, the "raider" threatened the targeted firms with tax office investigations, no access to public contracts, or other negative consequences. Thus, one respondent related the following anecdote:

"They buy up a lot of companies... They use mafia tools. They use the power of the state. [...] For example, I know of a media company, which made lamppost posters for parties during elections. They were always very careful to have 50-50 percent of Fidesz and 
MSZP on their posters. It is a private company. Some people went there and said, 'we would like to have 50 percent of your company for free'. As the company did not want to 'sell', after two months the same people went back and said, 'we want 80 percent of the company'. Then - when the owners still did not sell - after two weeks they introduced a law that forbids political posters on city lampposts. As a consequence, the market value of the firm went down to 10 percent [of its previous value]" (Respondent at Local07).

This anecdote highlights how failure to cooperate with the government leads to legal "retaliation" by the state. Several other interviewees confirm that threat of government retaliation can be enough to make company owners give up their company (Local17; NGO02)

Contrary to re-nationalizations, FBOs do not transfer ownership to the state, but directly to private individuals close to the governing elite. They are hence a sign of the deep penetration of private interests into the state sphere - the second erosion of the public-private divide normally protected by the rule of law - and imply that the state has become itself an economic actor that serves private interests.

\section{Discussion \& Conclusion}

The concept of "authoritarian capitalism" has merit in that it expands the varieties of capitalism approach to include important emerging market economies (Hofman et al., 2017) and alerts us to types of state intervention in the economy that go beyond its role in the idealtypical Western regulatory state (Situ et al., 2018). Yet, in this paper, we have shown that existing studies fail to provide a clear definition of the authoritarian nature of authoritarian capitalism. Often, they equate the Chinese reality with "authoritarianism." This approach limits the usefulness of the concept to understand other non-Western contexts.

Indeed, it is crucial for scholars to develop new conceptual tools to study the contexts of emerging economies, whose realities often defy Western academic concepts and theories (Bothello et al., 2019). "Authoritarian capitalism" can be such a concept if we define 
"authoritarianism" theoretically, rather than based on the Chinese empirical reality. Defining "authoritarian state intervention" as acts by the state that infringe key principles of the "Rule of Law" and conceptualizing it as implying a dual erosion of the divide between the public and the private, allows us to delimitate the concept more clearly. Furthermore, defining authoritarian capitalism as the erosion of the boundary between the political and the economic and the focus on the mechanisms that allow the governing elite to shift that boundary implies a dynamic view of the phenomenon whereby authoritarian capitalism is a process rather than a stable state as suggested by VoC-related categories.

The empirical case study of Hungary under Orbán's Fidesz government allowed us to identify in "abductive" fashion (Gioia et al., 2012, p. 21) mechanisms that contribute to the country's "backsliding" into more authoritarian forms of governance not just through "democratic backsliding" in the political sphere, but also through "economic backsliding" in the economic sphere. We thus contribute to the business and society literature, by furthering our understanding of the understudied process of the "politicization of the economic" (Gond et al, 2011). Studying this process in an extreme case allows us to open the black box of the state to understand how exactly the boundaries between the public and the private are shifted in the case of authoritarian capitalism.

We argue that all four mechanisms we identified - the creation of state dependence of economic actors, reducing economic pluralism to align the economic elite's interests with the governing elite's interests, the state being used for private rent extraction, and authoritarian shareholding - can be considered as part of a truly "authoritarian capitalist" state's arsenal in the sense that they all imply state action that disregards the principle of the RoL and are used to pursue the governing elite's private interests. As such, they constitute authoritarian capitalist tools in a narrower sense than what previous literature has suggested, which sees even perfectly legal and (legitimate) types of state intervention - such as the state exercising its ownership 
rights - as a sign of authoritarianism (cf. Situ et al., 2018). Thus defining "authoritarian capitalism" more precisely and more narrowly, avoids confusion between interventionist states and authoritarian states and allows us to distinguish "authoritarian capitalism" from "state capitalism." As such we offer new theoretical tools to distinguish in more nuanced manner different empirical phenomena that are usually lumped together under the designation of the "return of the state." Developing such theoretical and conceptual tools is important to equip Business and Society scholars with the means to understand the politicization of the economic that had disappeared from the radar of Business and Society scholarship since the 1980s.

We also contribute to the literature and study of post-socialist transition by extending the increasingly widely-used concept of "democratic backsliding" in the political sphere (e.g. Greskovtis, 2015) into the economic sphere. The mechanisms we identify contribute to what could be termed "economic backsliding" into more authoritarian forms of economic governance. As such, we complement the existing literature on the rise of political authoritarianism with its economic pendant, providing a completer picture of this important phenomenon.

One open question concerns the relationship between the four mechanisms we identify. As becomes clear from our empirical analysis, some of them are closely related. One distinction that can be made is between mechanism that erode the first political-economic divide (i.e. the boundary between the state and the economy) and those that affect more the second one (i.e. the boundary between state interests and private interests) (see figure 1). While these trends took place in parallel and several mechanisms may contribute to both trends at once, the Hungarian case does suggest that the economization of the public realm was often a precondition for the state becoming more interventionist in the economy once it had been colonized. Whether or not this is a necessary relationship is a question future research should address. 
In terms of the boundary conditions of our study, as a single country case study, our research is limited regarding its generalizability across-contexts. Moreover, given the sensitivity of the topic at hand and the political situation in Hungary, our firm sample may be subject to a self-selection bias. While we attempted to mitigate this bias as best we could, it is conceivable that certain sectors and companies perceive the state's role in a more positive light. This may be the case for instance in the export-orientated sectors. Future research should more systematically analyze such sectoral differences.

Finally, our discussion suggests that the "democratic backsliding" in the political sphere is paralleled by "backsliding" in the economic sphere. In other words, that political authoritarianism is matched with economic authoritarianism. This should not be seen as a universal feature of authoritarianism though, but rather the feature of the particular brand of "authoritarian capitalism" that is emerging in post-socialist countries. Indeed, history provides numerous examples of countries where authoritarianism and oppression in the political sphere, did not come at the expense of (private) businesses (cf. e.g. the case of South Korea, Deyo 1989). Similarly, based on our empirical case and our review of the literature, we found that the rise of "authoritarian capitalism" implies a dual erosion of the boundary between the state and the economy. Yet, our study does not allow us to ascertain whether the erosion of the second boundary - the colonization of the state by private interests - is a necessary condition for authoritarian capitalism, or whether the authoritarian extension into the private domain for private benefit can happen without the colonization of the state. More generally, while "backsliding" takes place in various post-socialist contexts (Sedelmeier, 2014; Greskovits, 2015; Bandelj et al., 2015) and it is very likely that our findings and conclusions apply to other cases too, future research should investigate the phenomenon in comparative fashion. This again points at the importance for future research to explore the boundary conditions of the “authoritarian capitalism" concept. 


\section{References}

Adam, Z., \& Simonovits, A. (2017). From democratic to authoritarian populism: Comparing pre- and post-2010 Hungarian pension policies, Discussion Papers, MT-DP - 2017/31: Institute of Economics, Institute of Economics, Centre for Economic and Regional Studies, Hungarian Academy of Sciences, Budapest.

Aguilera, R. V, Rupp, D. E., Williams, C. A., Ganapathi, J. (2007). Putting the S Back in Corporate Social Responsibility: A Multilevel Theory of Social Change in Organizations. Academy of Management Review, 32(3), 836-863.

Aßländer, M. S., \& Curbach, J. (2017). Corporate or Governmental Duties? Corporate Citizenship From a Governmental Perspective. Business and Society, 56(4), 617-645.

Bandelj, N., Finley, K., \& Radu, B. (2015). Democracy in Central and Eastern Europe: test of early impact. East European Politics, 31(2), 129-148

BBJ. (2012). Hungary's new nationalization plans could cost a fortune. Budapest Business Journal. Available at: http://www.bbj.hu/economy/hungarys-new-nationalizationplans-could-cost-a-fortune_64073.

Bozóki, A. (2011). Occupy the State: The Orbán Regime in Hungary. Debatte: Journal of Contemporary Central and Eastern Europe, 19, 649-663.

Böhm, A, (2004). Theoretical Coding: Text Analysis in Grounded Theory. In Uwe Flick, Ernst von Kardoff, Ines Steinke (Eds). A Companion to Qualitative Research, 270-275. London, Sage Publications 
Bothello, J., Nason, R. S., \& Schnyder, G. (2019). Institutional Voids and organization studies: Towards an epistemological rupture. Organization Studies. https://doi.org/10.1177/0170840618819037

Bremmer, I. (2008). The Return of Sate Capitalism. Survival, 50, 55-64.Bremmer, I. (2010). The end of the free market: Who wins the war between states and corporations. European View, 9, 249-252.

Bruton, G. D., Peng, M. W., Ahlstrom, D., Stan, C., \& Xu, K. (2015). State-owned Enterprises Around the World as Hybrid Organizations. Academy of Management Perspectives, 29(1), 92-114.

Budapestbeacon.com (2016). Is CBA part of Hungary's 'political mafia'?

Buckley, N., Byrne A., (2017, December 21.) Viktor Orbán 's oligarchs: a new elite emerges in Hungary, The Financial Times, Retrieved 18. December 2018 from https://www.ft.com/content/ecf6fb4e-d900-11e7-a039-c64b1c09b482

Bunge, M. (2004). How does it work? The search for explanatory mechanisms. Philosophy of the Social Sciences, 34(2), 182-210.

Carney, R. W., \& Witt, M. A. (2012). The Role of the State in Asian Business Systems. INSEAD Faculty \& Research Working Paper, 129, 1-25.

Cazurra, A. C., Inkpen, A., Musacchio, A., \& Ramaswamy, K. (2014). Governments as owners: State-owned multinational companies. Journal of International Business Studies, 45(8), 919-942.

Chen, D., \& Deakin, S. (2015). On Heaven's Lathe: State, Rule of Law, and Economic Development. Law and Development Review, 8(1), 123-145. 
Chidlow, A., Plakoyiannaki, E. \& Welch, C. (2014). Journal of International Business Studies 45: 562. https://doi.org/10.1057/jibs.2013.67

Davis, K. (1973). The Case for and Against Business Assumption of Social Responsibilities. Academy of Management Journal, 16(2), 312-322.

Day, M. (2010). Hungary nationalises toxic sludge aluminium company. The Telegraph, 12 Oct 2010 .

Dentchev, N. A., Haezendonck, E., \& van Balen, M. (2017). The Role of Governments in the Business and Society Debate. Business and Society, 56(4), 527-544.

Deyo, F. C. (1989). Labor and Development Policy in East Asia. The Annals of the American Academy of Political and Social Science, 505, 152-161.

Dicken, P. (2015). Global Shift. Mapping the Changing Contours of the World Economy (7th ed.). London: SAGE Publications.

Doner, R. F., Ritchie, B. K., \& Slater, D. (2005). Systemic Vulnerability and the Origins of Developmental States : Northeast and Southeast Asia in Comparative Perspective. International Organization, 59, 327-361.

Dunai, M. (2010. October 11). Factbox: Hungarian firm MAL, owner of burst red mud reservoir. Reuters. Retrieved 18. December 2018., from: http://www.reuters.com/article/2010/10/11/us-hungary-spill-malidUSTRE69A2YO20101011

EBRD (2005). Transition report 2005: Business in transition. London: European Bank for Reconstruction and Development.

Econews, M. (2012). Legislation gives gov't monopoly on tobacco sales, Econews, Budapest. 
Ekiert, G. (2012). The Illiberal Challenge in Post-Communist Europe. Taiwan Journal of Democracy, 8(2), 63-77.

Euractiv. (2012. September 5). Hungary to step up nationalisations. EurActive, Retrieved 18. December 2018, from: http://www.euractiv.com/central-europe/hungary-stepsnationalisations-news-514611.

Evans, P. (1995). Embedded Autonomy: State \& Industrial Transformation. Princeton: Princeton University Press.

Fainshmidt, S., Judge, W. Q., Aguilera, R. V, \& Smith, A. (2018). Varieties of institutional systems: A contextual taxonomy of understudied countries. Journal of World Business, 53(3), 307-322.

Freedom House (2017). Nations in Transit, Retrieved 6. September 2018. From https://freedomhouse.org/report/nations-transit/2017/hungary

Garriga, E., \& Melé, D. (2004). Corporate Social Responsibility Theories: Mapping the Territory Social Responsibility Corporate. Journal of Business Ethics, 53(1/2), 51-71.

Gioia, D. A., Corley, K. G., \& Hamilton, A. L. (2012). Seeking Qualitative Rigor in Inductive Research : Notes on the Gioia Methodology, 16(1), 15-31.

Golden Brian R. (1992) Research Notes. The Past is the Past-Or is it? The Use of Retrospective Accounts as Indicators of Past Strategy, Academy of Management Journal, 35(4), 848-860

Gond, J. P., Kang, N., \& Moon, J. (2011). The government of self-regulation: On the comparative dynamics of corporate social responsibility. Economy and Society, 40(4), $640-671$. 
Greskovits, B. (2015). The Hollowing and Backsliding of Democracy in East Central Europe. Global Policy, 6 (1), 28-37.

Gulyas, V. (2014). Court Says Hungary's Retail Tax Discriminates Against Competitors. The Wall Street Journal.Hajnal, G. \& Rosta, M. (2014). The illiberal state on the local level - The doctrinal foundations of subnational governance reforms in Hungary (20102014). Paper presented at EGPA Annual Conference, 10-12 September 2014. Speyer, Germany.

Hall, P. A., \& Soskice, D. (2001) Varieties of Capitalism: The Institutional Foundations of Comparative Advantage. Oxford University Press.

Hayek, F. A. (1960). The Constitution of Liberty. (R. Hamowy, Ed.). Chicago: University of Chicago Press.

Hedstrom, P., \& Ylikoski, P. (2010). Causal Mechanisms in the Social Sciences. Annual Review of Sociology, 36, 49-67.

Henderson, L. (1991). Authoritarianism and the Rule of Law. Indiana Law Journal, 66(2), $379-456$.

Hofman, P. S., Moon, J., \& Wu, B. (2017). Corporate Social Responsibility Under Authoritarian Capitalism: Dynamics and Prospects of State-Led and Society-Driven CSR. Business and Society, 56(5), 651-671.

Hollingsworth, J. R., \& Boyer, R. (1997). Contemporary Capitalism: The embeddedness of institutions. Cambridge: Cambridge University Press.

Inoue, C. F. K., Lazzarini, S. G., \& Musacchio, A. (2013). Leviathan as a Minority 
Shareholder: Firm-level implications of state equity purchases. Academy of Management Journal, 56(6), 1775-1801.

JM. (2013 July 10). Itt vannak a nemzeti dohányboltok. [National Tobacco stores are here], Index Retrieved 10.07.2013, from https://index.hu/gazdasag/2013/07/01/trafik/.

Kang, D. C. (2002). Bad Loans to Good Friends: Money Politics and the Developmental State in South Korea. International Organization, 56(1), 177-207.

Kornai, J. (2012). Centralisation and the Capitalist Market Economy in Hungary. CESifo Forum, 13, 47-59.

Kornai, J. (2015a). Hungary's U-Turn: Retreating from Democracy Journal of Democracy, 26(3), 34-48.

Kornai, J. (2015b). Hungary's U-Turn. Capitalism and Society, 10(1), 1-24.

Kovács, B. Á. (2015). Country Report Hungary, Nations in Transit 2015. Freedom House.

Kurlantzick, J. (2016). State Capitalism. How the Return of Statism is Transforming the World. Oxford: Oxford University Press.

Lawton, T., Rajwani, T., \& Doh, J. (2013). The antecedents of political capabilities: A study of ownership, cross-border activity and organization at legacy of airlines in a deregulatory context. International Business Review, 22(1), 228-242.

Ledeneva, A. V. (2013). Can Russia Modernise? Sistema, Power Networks and Informal Governance, Cambridge, UK, Cambridge University Press.

Lendvai, P. (2017). Orbán: Europe's New Strongman. Oxford, UK, Oxford University Press. Ma, Y. (2011). Market capitalism, state-style. Policy Review, 102-108. Ma, Y. (2011). Market capitalism, state-style. Policy Review, 102-108. 
Magyar, B. (Ed.) (2013). A Magyar Polip: A posztkommunista maffiaállam [The Hungarian Octopus: the post-communist mafia state, Noran Libri Press.

Magyar, B. (2016). Post-Communist Mafia State. The Case of Hungary. Budapest: Central European University Press.

Majone, G. (1994). The rise of the regulatory state in Europe. West European Politics, 17(3), $77-101$.

Martin, R. (2008). Post-socialist segmented capitalism: The case of Hungary. Developing business systems theory. Human Relations, 61(1), 131-159.

Martin, R. (2002). Politicized Managerial Capitalism: Enterprise structures in post-socialist Central and Eastern Europe. Journal of Management Studies, 39(6), 823-839.

Matten, D., \& Crane, A. (2005). Corporate Citizenship: Toward an Extended Theoretical Conceptualization. Academy of Management Review, 30(1), 166-179.

Matten, D., \& Moon, J. (2008). "Implicit" and "Explicit" CSR: A Conceptual Framework for a Comparative Understanding of Corporate Social Responsibility. Academy of Management Review, 33(2), 404-424.

Mihályi, Péter (2015): A privatizált vagyon visszaállamosítása, Magyarországon 2010 - 2014 (The renationalization of privatized assets in Hungary, 2010 - 2014) IEHAS Discussion Papers, No. MT-DP - 2015/7, ISBN978-615-5447-65-5

Miller, C. Chet, Cardinal, Laura B. and Glick, William H. (1997) Retrospective Reports in Organizational Research: A Reexamination of Recent Evidence, The Academy of Management Journal, 40 (1), 189-204 
Moon, J., Crane, A., \& Matten, D. (2005). Can Corporations Be Citizens? Corporate Citizenship as a Metaphor for Business Participation in Society. Business Ethics Quarterly, 15(3), 429-453.

Moon, J., Kang, N., \& Gond, J. P. (2010). Corporate Social Responsibility and Government. In D. Coen, W. Grant, \& G. Wilson (Eds.), The Oxford Handbook of Business and Government (pp. 1-42). Oxford: Oxford University Press.

Müller, J.-W. (2017). What Is Populism? London: Penguin Books.

Musacchio, A. (2008). Laws versus Contracts: Shareholder Protections and Ownership Concentration in Brazil, 1890-1950. Business History Review, 82(3), 445-473.

Musacchio, A., Lazzarini, S. G., \& Aguilera, R. V. (2015). New Varieties of State Capitalism: Strategic and Governance Implications. Academy of Management Perspectives, 29(1), 115-131.

Nagy, G., \& Szabo, M. I. (2013). Trafikmutyi: idegenek, képviselők és haverok sora. $H V G$. [Accessed 05.05.2013].

Negoita, M. (2006). The social bases of development: Hungary and Romania in comparative perspective, Socio-Economic Review, 4(2), 209-238.Novak, B, Kingsley P., (2018. December 12), Hungary Creates New Court System, Cementing Leader's Control of Judiciary, The New York Times, https://www.nytimes.com/2018/12/12/world/europe/hungary-courts.html [Accessed 17 December 2018].

OECD (2014). OECD Economic Surveys: Hungary 2014. OECD Publishing. OECD (2016). OECD Economic Surveys: Hungary 2016. Paris: OECD Publishing. 
Ohnesorge, J. (2007). The Rule of Law. Annual Review of Law and Social Science, 3, 99114.

Orenstein, M. A. (2013). Reassessing the neo-liberal development model in Central and Eastern Europe. In Schmidt, V. \& Thatcher, M. (eds.) Resilient Liberalism in Europe's Political Economy. Cambridge: Cambridge University Press.

Osborne, D., \& Gaebler, T. (1992). Reinventing Government: How the Entrepreneurial Spirit Is Transforming the Public Sector. New York City: Plume.

Piac És Profit. (2013). Nem lesz sikertörténet a trafiktörvény. Piac és Profit . [Accessed 20.04.2013].

Rajah, J. (2012). Authoritarian Rule of Law. Legislation, Discourse and Legitimacy in Singapore. Cambridge University Press.

Rochlitz, M. (2014). 'Corporate raiding and the role of the state in Russia', Post-Soviet Affairs, 30(2-3), 89-114.

Sallai, D. (2014). Europeanization of Corporate Lobbying in the Enlarged EU: The Missing Link in the Case of Hungary. Ph.D., King's College London.

Santora M., Bienvenu H. (2018) Hungary Election Was Free but Not Entirely Fair, Observers Say, $\quad$ Accessed $\quad$ 6. September, 2018, from https://www.nytimes.com/2018/04/09/world/europe/hungary-election-Orbán fidesz.html

Sass, M. (2017). Is a live dog better than a dead lion? Seeking alternative growth engines in the Visegrad countries. In Galgoczi, B. \& Drahokoupil, J. (eds.) Condemned to be left 
behind? Can Central and Eastern Europe emerge from its low-wage model? Brussels: ETUI - Brussels, pages: 47-79.

Scherer, A. G., \& Palazzo, G. (2011). The New Political Role of Business in a Globalized World: A Review of a New Perspective on CSR and its Implications for the Firm, Governance, and Democracy. Journal of Management Studies, 48(4), 899-931.

Scherer, A. G., \& Palazzo, G. (2007). Toward a Political Conception of Corporate Responsibility: Business and Society Seen From a Habermasian Perspective. Academy of Management Review, 32(4), 1096-1120.

Scherer, A. G., Palazzo, G., \& Matten, D. (2014). The Business Firm as a Political Actor: A New Theory of the Firm for a Globalized World. Business and Society, 53(2), 143-156.

Seawright, J., \& Gerring, J. (2008). Case Selection Techniques in Case Study Research A Menu of Qualitative and Quantitative Options. Political Research Quarterly, 61(2), 294-308.

Sedelmeier, U. (2014). Anchoring Democracy from Above? The European Union and Democratic Backsliding in Hungary and Romania after Accession. Journal of Common Market Studies, 52(1), 105-121.

Shamir, R. (2008). The age of responsibilization: On market-embedded morality. Economy and Society, 37(1), 1-19.

Situ, H., Tilt, C. A., \& Seet, P.-S. (2018). The influence of the government on corporate environmental reporting in China: An authoritarian capitalism perspective. Business and Society, In Press, 1-41. 
Strange, S. (1996). The Retreat of the State. The diffusion of power in the world economy. Cambridge: Cambridge University Press.

Tait, R. (2016). Protests in Hungary at closure of main leftwing opposition newspaper, The Guardian, Retrived 6 September 2018, from https://www.theguardian.com/world/2016/oct/09/protests-in-hungary-at-closure-ofmain-leftwing-opposition-newspaper .

Than, K. (2012). Hungary signs preliminary deal to buy E.ON gas units. Reuters, Retrieved 5 March 2019, from: http://www.reuters.com/article/2012/11/30/hungary-gasidUSL5E8MU5UQ20121130.

Transparancy International (2012) Corruption Risks in Hungary 2011: National Integrity Study. Berlin: Transparency International .

Wedel, J. R. (2003). Clans, cliques and captured states: rethinking 'transition' in Central and Eastern Europe and the Former Soviet Union. Journal of International Development, $15,427-440$.

Whitley, R. (2007) Business Systems and Organizational Capabilities Oxford: Oxford University Press.

Witt, M. A., Kabbach de Castro, L. R., Amaeshi, K., Mahroum, S., Bohle, D., \& Saez, L. (2017). Mapping the business systems of 61 major economies: a taxonomy and implications for varieties of capitalism and business systems research. Socio-Economic Review, in press, 1-34.

Witt, M. A., \& Redding, G. (2014). China : Authoritarian Capitalism. In M. A. Witt \& G. Redding (Eds.), The Oxford Handbook of Asian Business Systems (pp. 11-32). Oxford: Oxford University Press 